\title{
SLC18A2 wt Allele
}

National Cancer Institute

\section{Source}

National Cancer Institute. SLC18A2 wt Allele. NCI Thesaurus. Code C105071.

Human SLC18A2 wild-type allele is located in the vicinity of $10 \mathrm{q} 25$ and is approximately 38 $\mathrm{kb}$ in length. This allele, which encodes synaptic vesicular amine transporter protein, is involved in the subcellular localization of neurotransmitters. 